\title{
コニカルギヤの歯面損傷に及ぼす歯面修整の影響
}

熊谷 幸司 ${ }^{* 1}$, 森川 邦彦*1, 永原 幹雄 $^{* 2}$, 小森 雅晴 ${ }^{* 3}$

\section{Influence of Tooth Flank Modification on Tooth Surface Damage of Conical Involute Gears}

\author{
Kouji KUMAGAI ${ }^{* 1}$, Kunihiko MORIKAWA, Mikio NAGAHARA and Masaharu KOMORI \\ ${ }^{* 1}$ NISSAN MOTOR CO., LTD. \\ 1-1, Morinosatoaoyama, Atsugi-shi, Kanagawa, 243-0123, Japan
}

\begin{abstract}
The conical involute gears have been applied to automotive parts such as 4WD transfer. The conical gear pair has characteristic large ease off and this is equivalent to meshing of cylindrical gears which has large crowning for lead direction. Consequently, the trochoidal interference is thought to be caused because of tooth stiffness reduction. In this study, to clarify the influence of the tooth flank modification on the tooth surface damage, tooth surface endurance test with several tooth flank modification shapes is experimented. As a result, the gear pair with crowning for tooth profile direction and reverse crowning for lead direction can extend the pitting fatigue life because of the edge load reduction of tip or root.
\end{abstract}

Key Words : Conical Involute Gear, Ease Off, Tooth Flank Modification, Tooth Surface Damage, Contact Stress

\section{1. 緒言}

斜交軸配置が可能なコニカルインボリュートギヤは，FR4WD 車のトランスファー等，自動車にも適用される ようになってきた．このコニカルギヤ対は特有の大きな相対歯面誤差（Ease-off）形状を有し, 歯すじ方向に大き なクラウニングを施した円筒歯車のかみ合いと同様であるため, 歯の剛性の低下からトロコイド干渉を起こすこ とが考えられる.

本報告では, 大きな Ease-off 形状を有するコニカルギヤ対の歯面損傷の特徵およびそれに対する歯形中凸 修整や歯すじ方向逆クラウニング修整の影響を調べるため, 歯面修整形状の異なる複数のコニカルギヤ対に ついて歯面耐久試験をおこなった。

\section{2. コニカルギヤの歯面損傷}

\section{$2 \cdot 1$ 歯面耐久試験}

表 1 の歯車諸元のコニカルギヤ対を用いる. 各ギヤの円錐角は $5^{\circ}$ とした．トー側のアンダーカットを防止す るため, 転位係数の和が 0 となる設計基準点は歯幅中央よりト一側に約 $10.7 \mathrm{~mm}$ ずらした. この場合, 歯当たり位 置もト一側にずれるため, 組付軸角は各ギヤの円錐角の和より小さい $9^{\circ}$ とし，歯幅中央当たりとなるようにし た. また，ピニオンのブランク円錐角は $4^{\circ}$ とし，ヒール側トップランドを確保した．相対歯面誤差形状は図 1 の 3 パターンを用いる. 仕様 1 は各ギヤに歯面修整のないものであり，コニカルギヤ対特有の大きな相対歯面誤 差が生じている. 仕様 2 は歯先歯元のエッジコンタクト緩和のために歯形方向中凸修整 FFA $=10 \mu \mathrm{m}$ を施したもの である. 仕様 3 は歯形中凸修整に加えて歯すじ方向に逆クラウニング CRN=-10 $\mu \mathrm{m}$ を施したものである. 仕様 1 , 2 に比べて歯すじ方向の相対歯面誤差が緩和されているが，まだ作用平面の 4 隅に大きな隙間がみられる.

\footnotetext{
*1 正員, 日産自動車(株)（广243-0123 神奈川県厚木市森の里青山 1-1）

*2 日産自動車(株)

*3 正員, 京都大学大学院 工学研究科

E-mail:ku-kumagai@mail.nissan.co.jp
}

一般社団法人 日本機械学会 [No.13-17] MPT2013 シンポジウム＜伝動装置＞講演論文集［2013.11.14-16, 宮崎] 


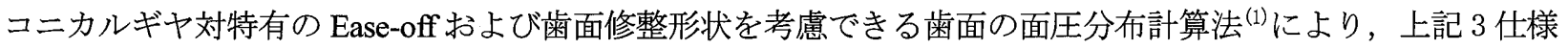
について面圧分布を計算した結果を図 2 に示す. ×印は最大面圧 $P_{\max }$ の位置を表しており, 歯幅中央よりややト 一側に寄っている.ここでは入力トルクは $300 \mathrm{Nm}$ とし，負荷時のデフレクションは考慮していない.いずれの仕 様も図 1 の相対歯面誤差形状とよく対応しており, 仕様 1 は歯面中央部が高面圧域となり,端部での大きなEase-off により特にヒール側で接触しない領域がある. 仕様 2 では最大面圧は大きくなるが，歯先歯元の面圧がやや緩和 されている. 仕様 3 は歯すじ方向の逆クラウニングによる面圧分布領域の拡がりにより, 最大面圧および歯先歯 元の面圧が緩和されている.

Table 1 Dimensions of test conical involute gears

\begin{tabular}{|l|c|}
\hline & Pinion/Gear \\
\hline Number of teeth & $16 / 31$ \\
\hline Normal module & 2.5 \\
\hline Pressure angle & $20^{\circ}$ \\
\hline Helix angle & $30^{\circ}(\mathrm{RH}) /-30^{\circ}(\mathrm{LH})$ \\
\hline Cone angle & $5^{\circ}$ \\
\hline Blank cone angle & $4^{\circ} / 5^{\circ}$ \\
\hline Tip diameter at toe & $52.96 / 92.76$ \\
\hline Tip diameter at heel & $57.15 / 98.01$ \\
\hline
\end{tabular}

\begin{tabular}{|l|c|}
\hline & Pinion/Gear \\
\hline Root diameter at toe & $40.161 / 79.963$ \\
\hline Root diameter at heel & $45.411 / 85.212$ \\
\hline Face width & 30 \\
\hline Shaft angle & $9^{\circ}$ \\
\hline Offset & 0.000 \\
\hline Mounting distance & $384.284 / 382.543$ \\
\hline $\begin{array}{l}\text { Shift coefficient at toe } \\
\text { edge point }\end{array}$ & $0.200 /-0.500$ \\
\hline
\end{tabular}

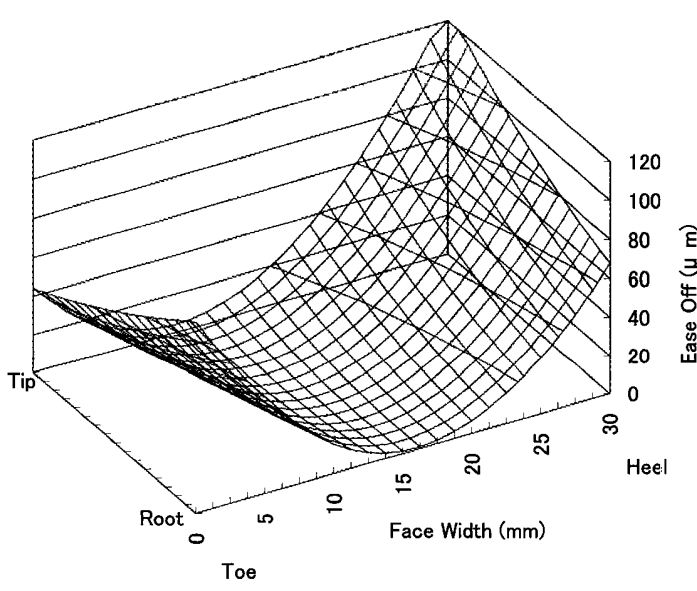

(Type 1) Without tooth surface modification

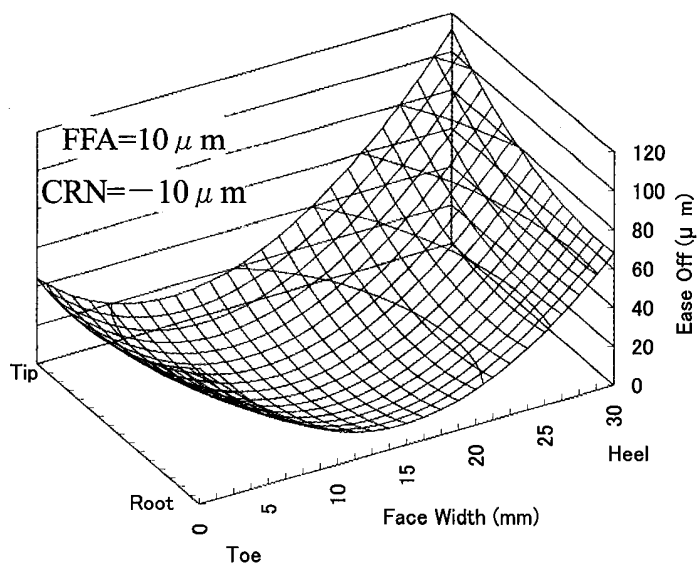

(Type 3) With crowning for tooth profile direction and reverse crowning for lead direction

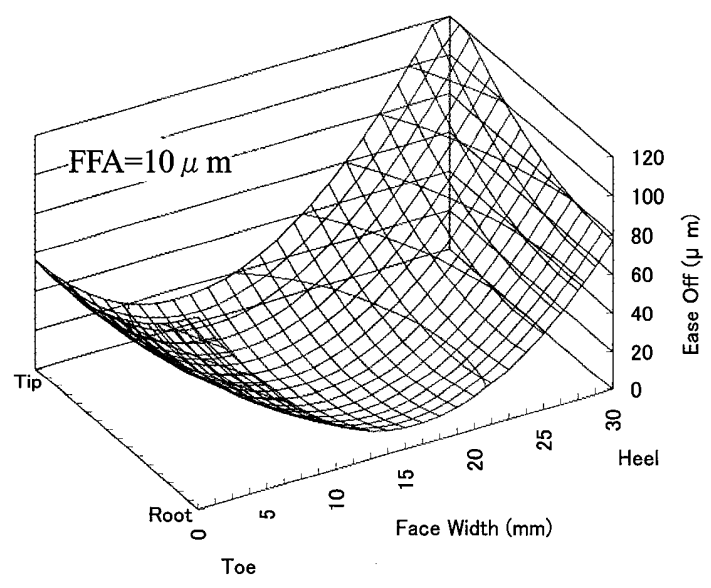

(Type 2) With crowning for tooth profile direction

Fig. 1 Relative tooth surface form (Ease off) of test conical gears 
30

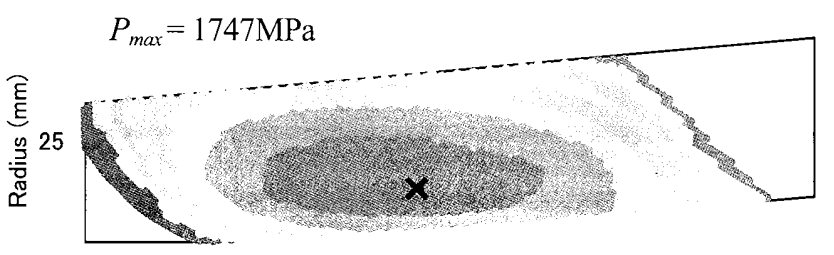

20

0

$10 \underset{\text { Face width }(\mathrm{mm})}{20}$

(Type 1)

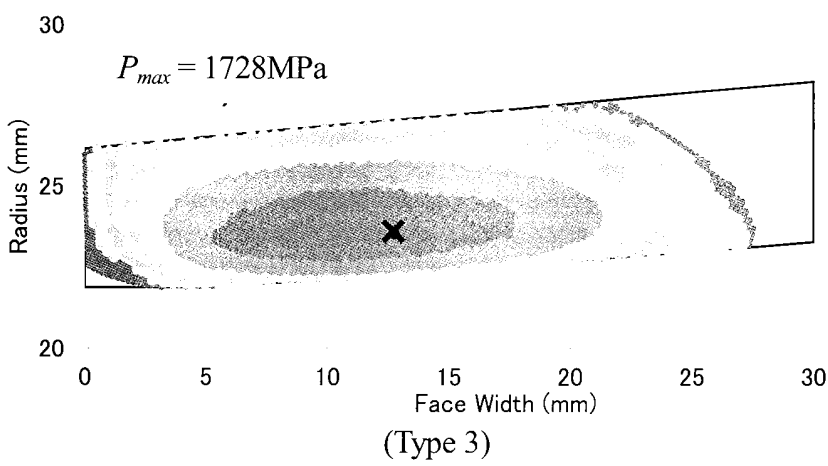

30

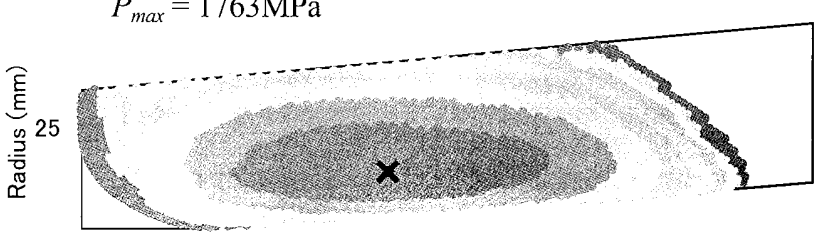

$0 \quad 5$

10

Face Width $\stackrel{20}{(\mathrm{~mm})}$

25

30

Fig. 2 Distribution of contact stress on plane of action of conical gear pair

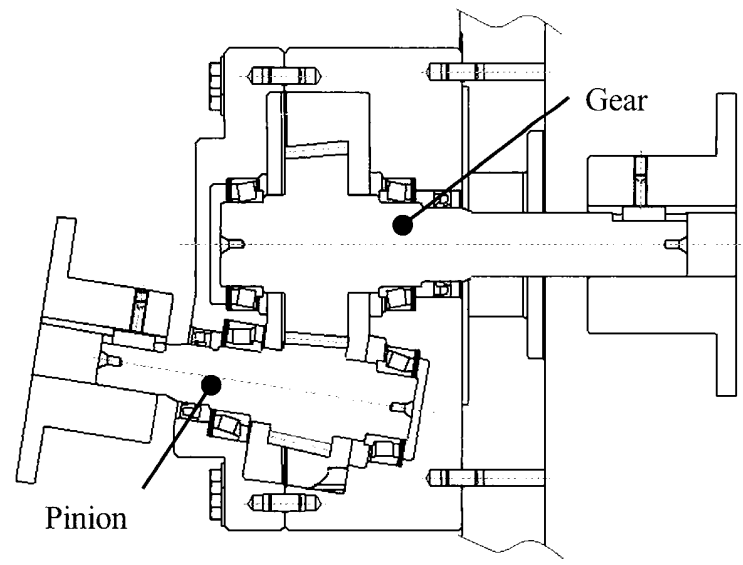

Fig. 3 Gearbox for tooth surface endurance test

これらのコニカルギヤ対を図 3 のギヤボックスに組み込み, 入力回転数 $2000 \mathrm{~min}^{-1}$, 入力トルク $300 \mathrm{Nm}$ で歯面耐 久試験をおこなった。潤滑油は $1 \mathrm{~L} / \mathrm{min}$ の ATF をかみ合い部へ強制潤滑し，油温は $80 \pm 2^{\circ} \mathrm{C}$ とし。供試ギヤの 材料は SCr420H で浸炭焼入焼戻しにより表面硬さを $730 \mathrm{Hv}$ 以上としている.

\section{$2 \cdot 2$ 歯面損傷進展状況}

図 4 に歯面耐久試験結果を示す.

仕様 1 では, $4 \times 10^{6}$ 回でピニオンの歯先にチッピングが発生し, それが進展して $6 \times 10^{6}$ 回で久損に至った. ま た，歯側端部は接触していないが，ピニオン歯幅中央の歯元部にトロコイド干渉と思われる痕がみられる.この ことから，コニカルギヤ対特有の大きな Ease-offにより歯側端部は接触しないが，歯幅中央では歯剛性の低下か ら，歯先歯元にトロコイド干渉によるエッジコンタクトが発生したと考えられる. 
仕様 2 では；仕様 1 で発生したチッピングはみられなかったが， $6 \times 10^{6}$ 回でピニオンの歯元にピッチングが発 生した.また，それが進展し $8 \times 10^{6}$ 回で歯の折損に至った. 歯形中凸修整により仕様 1 よりも歯先歯元のエッジ コンタクトは緩和されたと考えられるが，仕様 2 でもトロコイド干渉と思われる痕がみられる．また，トロコイ ド干渉域の付近にマイクロピッチングがみられ，ピットはその線上に発生していた.

仕様 3 では, $6 \times 10^{6}$ 回で仕様 2 よりも小さなピッチングが発生したが，その後 $10^{7}$ 回まで進展はなかった. 摩 耗により角が取れているように見える.ピッチング発生位置およびトロコイド干渉と思われる痕は仕様 2 よりも トー側に寄っている．ピットはトロコイド干渉域に発生していた．逆クラウニングにより歯すじ方向に接触領域 が拡がり，仕様 2 よりもエッジコンタクトは緩和されたと考えられるが，まだトロコイド干渉やマイクロピッチ ングが発生していた.

以上のことから，コニカルギヤでは適正な歯面修整によりトロコイド干渉による歯先歯元のエッジコンタクト の緩和が重要である.

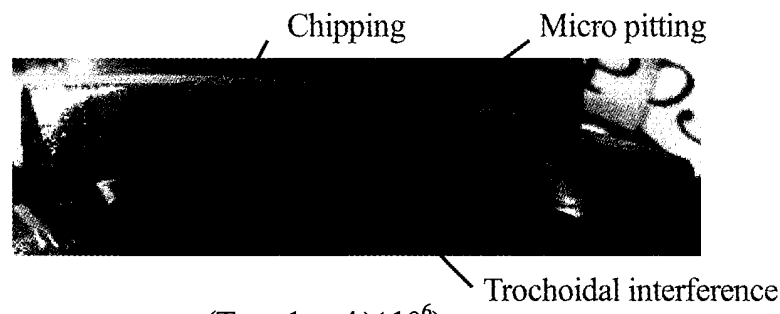

(Type $1,4 \times 10^{6}$ )

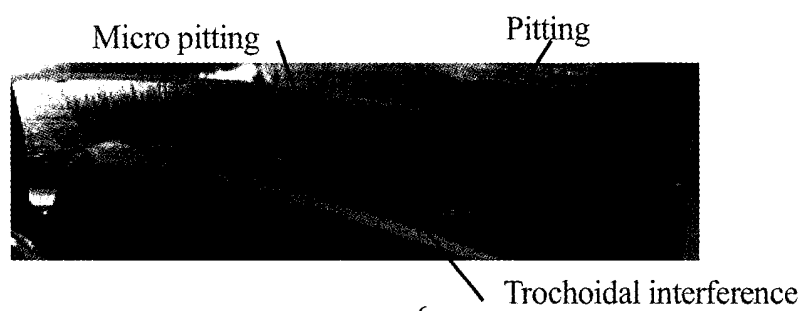

(Type $2,6 \times 10^{6}$ )

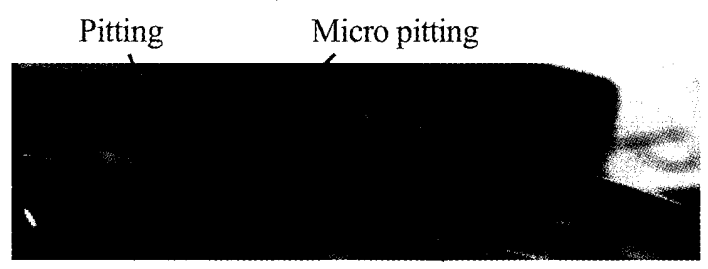

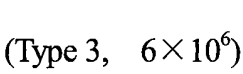

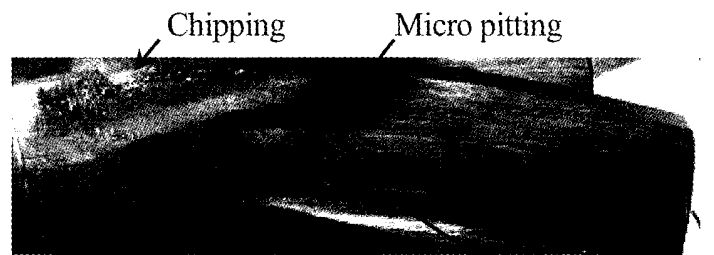

(Type 1, $6 \times 10^{6}$ )

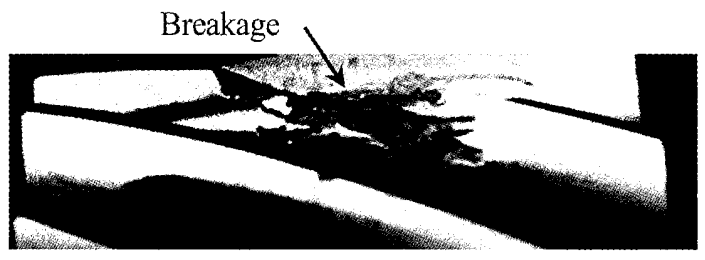

(Type $2,8 \times 10^{6}$ )

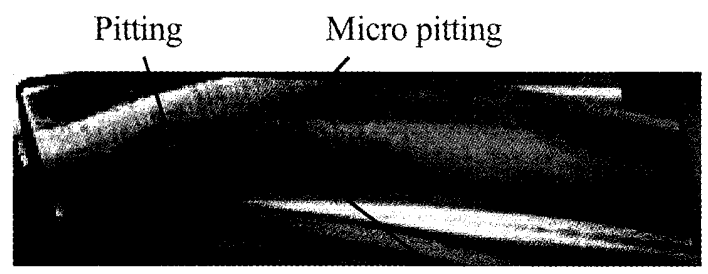

Trochoidal interference

(Type 3, $1 \times 10^{7}$ )

Fig.4 Result of tooth surface endurance test

図 5 は同じ材料, 熱処理の円筒歯車の同じ潤滑油下でのピッチング強度の S-N データ上に今回の耐久試験 結果をプロットしたものである.また，今回よりも大きな逆クラウニングを施し，エッジロードが緩和され た文献(1)のコニカルギヤの結果を合わせて示す. 図の縦軸は文献(1)の方法で求めた最大面圧の計算值であ り，本計算法ではエッジコンタクトによるエッジロードは計算できない. 今回の耐久結果と円筒歯車の $\mathrm{S}-\mathrm{N}$ 曲線の差は, エッジコンタクトによる歯先歯元のエッジロードが原因と考えられる. 歯面修整によりトロコ イド干渉を軽減してエッジコンタクトを緩和することで，耐久結果は円筒歯車の S-N 曲線に近づく.

今回の歯面修整量は円筒ギヤ並みの $10 \mu \mathrm{m}$ としたが, 適正な歯面修整によりエッジコンタクトをさらに軽 減できれば，円筒歯車の S-N 線図上にコニカルギヤのピッチング寿命も整理できるものと考えられる. 


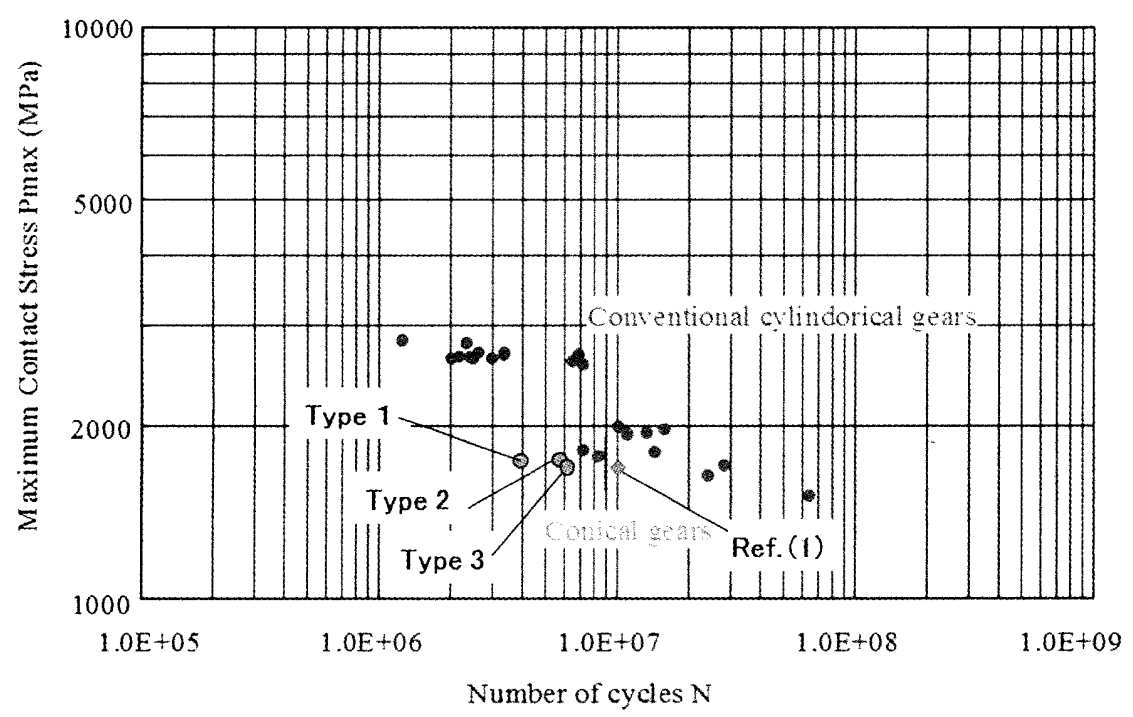

Fig.5 S-N plots of gear pitting

\section{3. 結 語}

大きな相対歯面誤差形状を有するコニカルギヤの歯面損傷の特徵およびそれに及ぼす歯面修整の影響を調べる ため，歯面耐久試験をおこない以下の結論を得た.

1.コニカルギヤのかみ合いでは，大きな Ease-offにより側端部のエッジコンタクトは発生しにくくなるが，円 筒歯車で大きなクラウニングを施した場合と同様に歯の剛性が低下し，歯先歯元部ではトロコイド干渉によ るエッジコンタクトが発生しやすく，歯面損傷に至る場合がある.

2. コニカルギヤのピッチング寿命を向上させるためには, 適切な逆クラウニングによる歯すじ方向への歯当た り幅の拡大および歯形中凸修整による歯先歯元の荷重分担の緩和をおこない，トロコイド干渉によるエッジ コンタクトを軽減することが重要である.

\section{文献}

（1）森川邦彦，熊谷幸司，永田真範，上田泉，小森雅晴，“コニカルギヤの歯面強度解析”，日本機械学会論文集 C 編， Vol. 79, No. 804 (2013), pp. 2952-2959. 